Original article

\title{
Immunostimulatory activity of schistosomula in mice
}

\author{
Reham A. Abdel Aleem ${ }^{1}$, Shreen S. El-Shaer ${ }^{2}$, Essam A. Afify ${ }^{2}$, Razin M. Abder Fattah ${ }^{1}$, Kareem S. Awad ${ }^{1}$, \\ Amany S. Maghraby ${ }^{1}$ \\ ${ }^{1}$ National Research Centre, Dokki, Giza, Egypt \\ ${ }^{2}$ Al-Azhar University, Cairo, Egypt
}

Received 26 March 2018, Revised 13 May 2018, Accepted 19 August 2018

(C) 2018, Abdel Aleem R.A., El-Shaer S.S., Afify E.A., Abder Fattah R.M., Awad K.S., Maghraby A.S.

C 2018, Russian Open Medical Journal

\begin{abstract}
Introduction - Our previous study cleared that both immunization with Egyptian Schistosoma mansoni schistosomula and therapy with praziquantel were able to induce significant levels of protection against re-infection as compared with immunization or treatment only.

Aim - The current study aimed to evaluate the immunostimulatory activity of schistosomula in naïve mice post injection with schistosomula either alone or with praziquantel to answer the question: can schistosomula be used as immunoadjuvant?

Material and Methods - Ten naïve mice were administered 3 doses of phosphate buffered saline. Ten mice injected with 500 schistosomula at day 0 and at $14^{\text {th }}$ day. Ten mice were administered praziquantel (PZQ) $(250 \mathrm{mg} / \mathrm{kg}$ body weight).Ten mice injected with schistosomula at day 0 and at $14^{\text {th }}$ day and received PZQ. The levels of IgM and IgG against soluble egg antigen (SEA) and soluble worm antigen preparation (SWAP) were detected by ELISA. Immunophenotyping of mesenteric lymph nodes (MLN) lymphocytes and thymocytes were carried out.

Results - IgM and IgG levels were significantly elevated in sera from mice injected with schistosomula alone or with PZQ or PZQ only. The mean percentage of $\mathrm{MLN} \mathrm{CD}^{+}, \mathrm{CD}^{+} \mathrm{T}$ and $\mathrm{B}$ lymphocytes were increased but considered not significant. The $\mathrm{MLN} \mathrm{CD4}^{+} / \mathrm{CD}^{+} \mathrm{T}$ ratios were $>1$. The mean $\%$ of $\mathrm{CD}^{+}$and $\mathrm{CD} 8^{+}$thymocytes were increased and the $\mathrm{CD} 4^{+} / \mathrm{CD} 8^{+}$thymocytes ratios were $>1$.

Conclusion - Immunostimulatory activity schistosomula was detected by enhancing lgs titers, stimulating the mean $\%$ of $\mathrm{CD} 4^{+}, \mathrm{CD} 8^{+} \mathrm{T}, \mathrm{B}-$ MLN cells and thymocytes $\mathrm{CD}^{+}, \mathrm{CD}^{+} \mathrm{T}^{\mathrm{C}} \mathrm{CD} 4^{+} / \mathrm{CD} 8^{+} \mathrm{T}$ cells ratios were $>1$ in $\mathrm{MLN}$ and thymus gland.
\end{abstract}

Keywords: immunostimulatory, schistosomula, mesenteric lymph nodes, thymus, CD4+/CD8+ T lymphocytes ratio, B-lymphocytes.

Cite as Abdel Aleem RA, El-Shaer SS, Afify EA, Abder Fattah RM, Awad KS, Maghraby AS. Immunostimulatory activity of schistosomula in mice. Russian Open Medical Journal 2018; 7: e0407.

Correspondence to Amany Sayed Maghraby. E-mail: as.maghraby@nrc.sci.eg.

\section{Introduction}

Schistosomiasis, a debilitating disease caused by trematode blood flukes of the genus Schistosoma, is recognized as the most important human helminth infection in terms of morbidity and mortality. According to the world health organization, schistosomiasis affects about 250 million people worldwide [1].

Schistosoma mansoni infection occurs after direct contact with freshwater harboring free swimming cercariae which penetrate the skin of humans and enter capillaries and lymphatic vessels en route to the lungs. After several days, the schistosomula migrate to the portal venous system, where they mature and unite. Then migrate to superior mesenteric veins. Eggs are deposited in the vein lumen and pass into the host tissues, and then many pass through the intestinal mucosa and are shed in the feces [2].

Despite the existence of praziquantel (PZQ), schistosomiasis is spreading into new areas, PZQ chemotherapy does have limitations. In particular, mass treatment does not prevent reinfection. Furthermore, the prospect of relying on a single drug is of concern and the potential for drug resistance, particularly in areas of high transmission must be considered $[3,4]$.
Consequently, vaccine strategies represent an essential component for the future control of schistosomiasis as an adjunct to chemotherapy. These vaccines function mainly through inducing specific antibody responses or activating $\mathrm{CD4}^{+}-\mathrm{T}$ cells against schistosomula or adult worms $[5,6]$. However, the role of $\mathrm{CD}^{+}-\mathrm{T}$ cell responses has been considered as a potential aspect in the development of vaccine against schistosomiasis [7]. Evidence indicated that an $\mathrm{Ag}$ specific $\mathrm{CD} 8^{+}-\mathrm{T}$ cell response was induced in schistosome infected mice $[8,9]$.

Vaccines efficacy is directly related to adjuvant effect that prolong the immunological memory of vaccines and broaden the antibody repertoire. Adjuvants can drive the immune system to a Th1, Th2 or mixed Th1/Th2 response [10].

Lung schistosomula are more efficient stimulators of lymphocyte proliferation and secretion of Th1 cytokines than those from cercariae and skin-stage larvae [11, 12]. Immunization of mice with schistosomula tegument (Smteg) plus Freunds adjuvant, characterized by IFN- $\gamma, \operatorname{IgG} 1$ and $\operatorname{IgG} 2 \mathrm{c}$ production, induced damage in parasite tegument $[13,14]$. The objective of the present study is to determine the immunostimulatory activity of Egyptian S. mansoni schistosomula on cellular and humoral 
immune responses. In addition, can schistosomula be used as immuno-adjuvant?

\section{Material and Methods}

Animals

A total of 40 female Swiss albino mice, 18-20 gram, were used. Animals were fed on standard chew, supplied with water and maintained at ambient temperature $25^{\circ} \mathrm{C}$.

Schistosomula - Egyptian S. mansoni schistosomula were prepared from cercariae of $S$. mansoni strain according to James and Taylor [15].

Praziquantel - (Biltricide $^{\circledR}$ - manufactured by Alexandria co. for Pharmaceuticals and Chemical. Ind., Alexandria, Egypt under license of BAYER Leverkusen, Germany) was suspended in $0.01 \mathrm{M}$ phosphate buffered saline (PBS), pH 7.2.

\section{Experimental groups}

Group1: A total of 40 female Swiss albino mice were divided into ten naïve mice were orally administered 3 doses of phosphate buffered saline and maintained at the same condition to be used as normal group.

Group 2: Ten mice were subcutaneously injected with 500 schistosomula at day 0 and received the second dose at $14^{\text {th }}$ day. Post $1^{\text {st }}$ and $2^{\text {nd }}$ injections, blood samples were collected from each individual mouse via optical vein and sera were separated.

Group 3: Ten mice were orally administered 3 doses of PZQ ( $250 \mathrm{mg} / \mathrm{kg}$ body weight). After each dose of $\mathrm{PZQ}$, individual serum was separated.

Group 4: Ten mice were injected with schistosomula at day 0 and received the second dose at $14^{\text {th }}$ day followed by administration of 3 doses of PZQ at the same time of the Group 2. After the last dose of PZQ individual blood samples were collected and sera were separated and frozen at $-80^{\circ} \mathrm{C}$ till being used.

\section{Determination of antibody titers in the mice sera by enzyme linked immune-sorbent assay (ELISA)}

The levels of IgM and IgG in sera from animals were detected by ELISA according to Maghraby \& Bahgat [16]. Plates were coated with $(50 \mu \mathrm{l} /$ well) of soluble worm antigen preparation (SWAP: 50 $\mu \mathrm{g} / \mathrm{ml}$ ) and soluble egg antigen (SEA: $50 \mu \mathrm{g} / \mathrm{ml}$ ). Antigen free sites were blocked against non-specific binding using (100 $\mu \mathrm{l} /$ well) of phosphate buffered saline containing $0.05 \%$ Tween $20-5 \%$ fetal calf serum (PBST-FCS) and incubated at $37^{\circ} \mathrm{C}$ for $1 \mathrm{~h}$. After thee washes with phosphate buffered saline containing $0.05 \%$ Tween-20 (PBST20), diluted sera (1:50) in PBST-FCS were applied (50 $\mu \mathrm{l} /$ well) and plates were incubated at $37^{\circ} \mathrm{C}$ for $2 \mathrm{~h}$. For total IgG detection, peroxidase conjugated anti-mouse IgG $(\mathrm{H}+\mathrm{L})$ was added $(50$ $\mu \mathrm{l} /$ well) at 1:500 dilution in PBST-FCS and plates were incubated at $37^{\circ} \mathrm{C}$ for $1 \mathrm{~h}$. For IgM Goat- anti mouse IgM $(\mu)$ conjugated with Horseradish peroxidase was added $(50 \mu \mathrm{l} /$ well) at 1:500 dilutions in PBST-FCS and plates were incubated at $37^{\circ} \mathrm{C}$ for $1 \mathrm{~h}$. For color development, a volume of $(100 \mu \mathrm{l} /$ well $)$ of Orthophenylenediamine (OPD) (Sigma, St. Louis, Mo, USA) diluted in substrate buffer and left for $10 \mathrm{~min}$ at room temperature till color development. The enzymatic reaction was stopped using 50 $\mu \mathrm{l}$ of $2 \mathrm{M} \mathrm{HCl}$ and the changes in optical density (OD) were recorded at $\lambda \max 490 \mathrm{~nm}$ using a multi-well plate reader (139 Tecan; Sunrise, $\mathrm{GmbH}$, Grödig, Austria).
Table 1. Determination of IgM level in sera from schistosomula or/and PZQ administered mice against SWAP

\begin{tabular}{lc}
\hline \multicolumn{1}{c}{ Experimental groups } & Mean $\pm S D$ \\
\hline Group 1 & $0.183 \pm 0.038$ \\
Group 2 & \\
$-1^{\text {st }}$ dose of PZQ & $0.406 \pm 0.076^{*}$ \\
$-2^{\text {nd }}$ dose of PZQ & $0.453 \pm 0.086^{* *}$ \\
$-3^{\text {rd }}$ dose of PZQ & $0.586 \pm 0.062^{* *}$ \\
Group 3 & \\
$-1^{\text {st }}$ injection & $0.566 \pm 0.157^{* *}$ \\
$-2^{\text {nd }}$ injection & $0.703 \pm 0.054^{* *}$ \\
Group 4 & $0.635 \pm 0.084^{* *}$ \\
\hline
\end{tabular}

"Significant values $\mathrm{P}<0.01 ;{ }^{* *}$ Significant values $\mathrm{P}<0.001$.

Group1: PBS administered naïve mice; used as negative control group. Group 2: PZQ administered mice $\left(1^{\text {st }}, 2^{\text {nd }}\right.$ and $3^{\text {rd }}$ dose). Group 3: Schistosomula injected mice $\left(1^{\text {st }}\right.$ and $2^{\text {nd }}$ dose). Group 4: Schistosomula-PZQ administered mice.

\section{Immunophenotyping of different lymphocytes populations}

Mesenteric lymph nodes (MLNs) and thymus were excised, gently teased in petri dishes containing PBST-FCS using glass slides. Cells from individual mouse were washed three times with PBSTFCS followed by centrifugation at $1500 \mathrm{~g}$ at $4^{\circ} \mathrm{C}$ for $10 \mathrm{~min}$. CD4 ${ }^{+}$, $\mathrm{CD}^{+} \mathrm{T}$-cell subsets were identified by labeling with fluorescence isothiocyanate (FITC) conjugated monoclonal anti-mouse CD4 ${ }^{+}$, $\mathrm{CD}^{+}$respectively (Biolegend San Diego, CA, USA) while, B-cells were labeled by FITC labeled anti-mouse IgG $(\mathrm{H}+\mathrm{L})$ chain $(\mathrm{KPL})$. To calculate the mean percentage of $\mathrm{CD}^{+}, \mathrm{CD}^{+}{ }^{-} \mathrm{T}-$ and $\mathrm{B}$ lymphocytes, the green fluorescence stained lymphocytes were counted in a minimum of 100-200 viable cells using a fluorescence microscope (Zeiss Axioskop, Jena, Germany) according to Maghraby [17].

\section{Statistical analysis}

All obtained data were analyzed by the Students't-test using the Graph Pad InStat Software. The data were expressed as mean with standard deviation - Mean \pm SD. Data were considered significant when P-values were $<0.05$. The non significanct data were represented as: N.S.

\section{Results}

Determination of IgM level in sera from schistosomula or/and $P Z Q$ administered mice against SWAP

Post $1^{\text {st }}$ and $2^{\text {nd }}$ injections with schistosomula, IgM level in sera from schistosomula injected mice was significantly increased $(P<0.001)$ as compared with negative control level. Although the $2^{\text {nd }}$ dose $(0.70 \pm 0.05)$ showed higher IgM level than $1^{\text {st }}$ dose $(0.57 \pm 0.16$; fold $=1.24)$, the difference was not considered significant ( $P>0.05)$ (Table 1$)$.

The IgM level was significantly increased $(P<0.01,0.01,0.001)$ in sera from mice post $1^{\text {st }}, 2^{\text {nd }}$ and $3^{\text {rd }}$ doses of PZQ respectively as compared with normal level. Although the $3^{\text {rd }}$ dose showed higher IgM response $(0.59 \pm 0.06)$ than the $1^{\text {st }}$ dose $(0.41 \pm 0.08$; fold $=1.44)$ and the $2^{\text {nd }}$ dose $(0.45 \pm 0.09$; fold $=1.29)$, the differences among the 3 doses were not significant $(P>0.05)$ (Table 1$)$.

The IgM level in sera from schistosomula-PZQ administered mice showed significant increase $(P<0.001)$ as compared with normal level. The IgM level in sera from this group $(0.64 \pm 0.08)$ showed significant increase $(P<0.05)$ as compared with that from 
PZQ administered mice after $1^{\text {st }}$ dose of PZQ (0.41 \pm 0.08$)$. However, it showed non-significant increase $(P>0.05)$ when compared with IgM level in sera from mice administered the $2^{\text {nd }}(0.45 \pm 0.09$; fold=1.4) or the $3^{\text {rd }}(0.59 \pm 0.06$; fold $=1.08)$ doses of PZQ. It was also observed that the IgM level in sera from schistosomula-PZQ administered mice showed non-significant changes $(P>0.05)$ as compared with schistosomula injected mice (Table 1).

\section{Determination of lgG level in sera from schistosomula or/and}

\section{$P Z Q$ administered mice against SWAP}

Post $1^{\text {st }}$ and $2^{\text {nd }}$ injections with schistosomula, IgG level in sera from injected mice was significantly increased $(P<0.001)$ as compared with normal level. Although the $2^{\text {nd }}$ dose $(0.63 \pm 0.07)$ showed higher lgG level than $1^{\text {st }}$ dose $(0.47 \pm 0.07$; fold $=1.33)$, the difference was not considered significant $(P>0.05)$ (Table 2).

The IgG level was significantly increased $(P<0.001)$ in sera from PZQ administered mice post $1^{\text {st }}, 2^{\text {nd }}$ and $3^{\text {rd }}$ dose as compared with normal level. Although the $3^{\text {rd }}$ dose showed higher IgG response $(0.54 \pm 0.03)$ than the $1^{\text {st }}$ dose $(0.46 \pm 0.08$; fold $=1.19)$ and the $2^{\text {nd }}$ dose $(0.47 \pm 0.14$; fold $=1.16)$, the differences among the 3 doses were not significant $(P>0.05)$ (Table 2).

The IgG level in sera from schistosomula-PZQ administered mice showed a significant increase $(P<0.001)$ as compared with normal level. However, the IgG level in sera from this group showed non-significant increase $(P>0.05)$ when compared with IgG level in sera from PZQ administered mice after the $1^{\text {st }}(0.46 \pm 0.08$; fold $=1.3), 2^{\text {nd }}(0.47 \pm 0.14$; fold $=1.27)$ and $3^{\text {rd }}(0.54 \pm 0.03$; fold $=$ 1.09) doses of PZQ. It was also observed that the IgG level in sera from schistosomula-PZQ administered mice showed nonsignificant changes $(P>0.05)$ as compared with schistosomula injected mice (Table 2).

Determination of IgM level in sera from schistosomula injected or/and PZQ administered mice against SEA

Post $1^{\text {st }}$ and $2^{\text {nd }}$ injections with schistosomula, IgM level in sera from injected mice was significantly increased $(P<0.001)$ as compared with normal level. Although the $2^{\text {nd }}$ dose $(0.79 \pm 0.10)$ showed higher IgM level than $1^{\text {st }}$ dose $(0.68 \pm 0.13$; fold $=1.16)$, the difference was not significant $(P>0.05)$ (Table 3$)$. The IgM level was significantly increased $(P<0.01,0.001,0.001)$ in sera from mice post $1^{\text {st }}, 2^{\text {nd }}$ and $3^{\text {rd }}$ doses of PZQ respectively as compared with normal level. Although the $3^{\text {rd }}$ dose showed higher IgM response $(0.58 \pm 0.04)$ than the $1^{\text {st }}$ dose $(0.39 \pm 0.09$; fold $=1.49)$ and the $2^{\text {nd }}$ dose $(0.52 \pm 0.14$; fold $=1.13)$, the differences among the 3 doses were not significant $(\mathrm{P}>0.05)$ (Table 3 ).

The IgM level in sera from schistosomula-PZQ administered mice showed significant increase $(P<0.001)$ as compared with normal level. The IgM level in sera from this group showed significant increase $(P<0.01)$ as compared with that from mice administered the $1^{\text {st }}$ dose of PZQ $(0.39 \pm 0.09)$. However, it showed non-significant increase $(P>0.05)$ when compared with IgM level in sera from PZQ administered mice after the $2^{\text {nd }}(0.52 \pm 0.14$; fold= 1.22 ) and the $3^{\text {rd }}(0.58 \pm 0.04$; fold $=1.08)$ doses of $P Z Q$. It was also observed that the IgM level in sera from schistosomula-PZQ administered mice showed non-significant changes $(P>0.05)$ as compared with schistosomula injected mice (Table 3).
Table 2. Determination of IgG level in sera from schistosomula -or/and PZQ administered mice against SWAP

\begin{tabular}{lc}
\hline \multicolumn{1}{c}{ Experimental groups } & Mean $\pm S D$ \\
\hline Group 1 & $0.178 \pm 0.032$ \\
Group 2 & \\
$-1^{\text {st }}$ dose of PZQ & $0.458 \pm 0.079^{* *}$ \\
$-2^{\text {nd }}$ dose of PZQ & $0.467 \pm 0.014^{* *}$ \\
$-3^{\text {rd }}$ dose of PZQ & $0.544 \pm 0.029^{* *}$ \\
Group 3 & \\
$-1^{\text {st }}$ injection & $0.472 \pm 0.073^{* *}$ \\
$-2^{\text {nd }}$ injection & $0.630 \pm 0.066^{* *}$ \\
Group 4 & $0.595 \pm 0.069^{* *}$ \\
\hline
\end{tabular}

Significant values at $P<0.001$

Group1: PBS administered mice; used as negative control. Group 2: PZQ administered mice $\left(1^{\text {st }}, 2^{\text {nd }}\right.$ and $3^{\text {rd }}$ dose). Group 3: Schistosomula injected mice ( $1^{\text {st }}$ and $2^{\text {nd }}$ dose). Group 4: Schistosomula-PZQ administered mice.

Table 3. Determination of IgM level in sera from schistosomula injected or/and PZQ administered mice against SEA

\begin{tabular}{lc}
\hline \multicolumn{1}{c}{ Experimental groups } & Mean $\pm S D$ \\
\hline Group 1 & $0.192 \pm 0.039$ \\
Group 2 & \\
$-1^{\text {st }}$ dose of PZQ & $0.393 \pm 0.086^{*}$ \\
$-2^{\text {nd }}$ dose of PZQ & $0.516 \pm 0.135^{* *}$ \\
$-3^{\text {rd }}$ dose of PZQ & $0.584 \pm 0.044^{* *}$ \\
Group 3 & \\
$-1^{\text {st }}$ injection & $0.677 \pm 0.126^{* *}$ \\
$-2^{\text {nd }}$ injection & $0.788 \pm 0.102^{* *}$ \\
Group 4 & $0.628 \pm 0.070^{* *}$ \\
\hline
\end{tabular}

"Significant values $\mathrm{P}<0.01 ;$ Significant values $\mathrm{P}<0.001$.

Group1: PBS administered naïve mice; used as negative control group. Group 2: PZQ administered mice $\left(1^{\text {st }}, 2^{\text {nd }}\right.$ and $3^{\text {rd }}$ dose). Group 3: Schistosomula injected mice ( $1^{\text {st }}$ and $2^{\text {nd }}$ dose). Group 4: Schistosomula-PZQ administered mice.

Table 4. Determination of IgG level in sera from schistosomula or/and PZQ administered mice against SEA

\begin{tabular}{lc}
\multicolumn{1}{c}{ Experimental groups } & Mean $\pm S D$ \\
\hline Group 1 & $0.157 \pm 0.038$ \\
Group 2 & \\
$-1^{\text {st }}$ dose of PZQ & $0.439 \pm 0.036^{* *}$ \\
$-2^{\text {nd }}$ dose of PZQ & $0.429 \pm 0.046^{* *}$ \\
$-3^{\text {rd }}$ dose of PZQ & $0.592 \pm 0.074^{* *}$ \\
Group 3 & \\
$-1^{\text {st }}$ injection & $0.407 \pm 0.061^{* *}$ \\
$-2^{\text {nd }}$ injection & $0.428 \pm 0.015^{* *}$ \\
Group 4 & $0.452 \pm 0.035^{* *}$ \\
\hline
\end{tabular}

Significant values at $P<0.001$.

Group1: PBS administered mice; used as negative control Group 2: PZQ administered mice $\left(1^{\text {st }}, 2^{\text {nd }}\right.$ and $3^{\text {rd }}$ dose). Group 3: Schistosomula injected mice $\left(1^{\text {st }}\right.$ and $2^{\text {nd }}$ dose). Group 4: Schistosomula-PZQ administered mice.

Determination of IgG level in sera from schistosomula or/and PZQ administered mice against SEA

Post $1^{\text {st }}$ and $2^{\text {nd }}$ injections with schistosomula, lgG level in sera from immunized mice was significantly increased $(P<0.001)$ as compared with normal level. Although the $2^{\text {nd }}$ dose $(0.43 \pm 0.02)$ showed higher lgG level than $1^{\text {st }}$ dose $(0.41 \pm 0.06$; fold=1.05), the difference was not significant $(\mathrm{P}>0.05)$ (Table 4). The IgG level was significantly increased $(P<0.001)$ in sera from PZQ administered mice post $1^{\text {st }}, 2^{\text {nd }}$ and $3^{\text {rd }}$ doses as compared with normal level. Although the $3^{\text {rd }}$ dose showed higher $\lg$ response $(0.59 \pm 0.07)$ than the $1^{\text {st }}$ dose 
$(0.44 \pm 0.04$; fold $=1.35)$ and the $2^{\text {nd }}$ dose $(0.43 \pm 0.05$; fold $=1.38)$, the differences among the 3 doses were not significant $(P>0.05)$ (Table 4$)$.

The IgG level in sera from schistosomula-PZQ administered mice showed significant increase $(P<0.001)$ as compared with normal level. There were non-significant changes $(P>0.05)$ in IgG levels in sera among schistosomula-PZQ administered mice $(0.45 \pm 0.04)$ and either the schistosomula injected mice or the PZQ administered mice (Table 4).

\section{Mean percentage of thymocytes from schistosomula or/and} PZQ administered mice

Post $1^{\text {st }}$ and $2^{\text {nd }}$ injections with schistosomula, the mean percentage (\%) of $\mathrm{CD}^{+}$or $\mathrm{CD}^{+}$thymocytes showed nonsignificant changes $(P>0.05)$ as compared with normal thymocytes $\%$. Although $2^{\text {nd }}$ schistosomula injected mice showed higher mean $\%$ of $\mathrm{CD}^{+}$or $\mathrm{CD}^{+}$thymocytes $(43.2 \pm 1.3,35.0 \pm 1.4$ respectively) than $1^{\text {st }}$ schistosomula injected mice $42.0 \pm 2.0$ (fold=1.03), 33.1 \pm 2.1 (fold $=1.06$ ) respectively, these increments were not considered significant ( $P>0.05$ ) (Table 5).

PZQ administered mice showed non-significant change $(\mathrm{P}>0.05)$ in the mean \% of $\mathrm{CD}^{+}$or $\mathrm{CD}^{+}$thymocytes as compared with naïve thymocytes mean \% (Table 5).

Schistosomula-PZQ administered mice showed non-significant changes $(P>0.05)$ in the mean percentage of $\mathrm{CD}^{+}$or $\mathrm{CD}^{+}$ thymocytes as compared with the mean normal thymocytes \%. They showed non-significant increments $(P>0.05)$ in CD4+ thymocytes when compared with schistosomula $1^{\text {st }}$ injected mice $(42.0 \pm 2.0$; fold $=1.04)$ or $2^{\text {nd }}$ injected mice $(43.2 \pm 1.3$; fold $=1.009)$ or PZQ administered mice $(42.3 \pm 3.3$; fold $=1.03)$. It was also observed that the mean \% of $\mathrm{CD}^{+}$thymocytes from schistosomula-PZQ administered mice $(33.3 \pm 1.3)$ showed non-significant changes $(\mathrm{P}>0.05)$ as compared with the mean percentage of $\mathrm{CD}^{+}$ thymocytes from $1^{\text {st }}$ schistosomula injected mice $(33.1 \pm 2.1$; fold $=1.00$ ) or $2^{\text {nd }}$ schistosomula injected mice $(35.0 \pm 1.4)$ or PZQ administered mice $(35.1 \pm 2.7)$ respectively (Table 5).

\section{Mean percentage of mesenteric lymph nodes (MLN) lymphocytes} from schistosomula injected or/and PZQ administered mice

Post $1^{\text {st }}$ and $2^{\text {nd }}$ injections with schistosomula, the mean percentage (\%) of $\mathrm{CD}^{+} \mathrm{T}$ or $\mathrm{CD} 8^{+} \mathrm{T}$ or $\mathrm{B}$ cells showed non-significant changes $(P>0.05)$ as compared with the mean \% of naïve control MLN cells. Although schistosomula $2^{\text {nd }}$ injected mice $(38.0 \pm 2.0$, 44.2 \pm 3.8 ) showed higher mean $\%$ of $\mathrm{CD}^{+} \mathrm{T}$ and $\mathrm{B}$ cells respectively than $1^{\text {st }}$ injected mice $(37.3 \pm 3.1$; fold $=1.02,38.0 \pm 3.9$; fold=1.16), these increments were not considered significant $(P>0.05)$. It was observed that schistosomula $2^{\text {nd }}$ injected mice $(28.7 \pm 0.6)$ showed significant increase $(P<0.05)$ in the mean \% of $\mathrm{CD}^{+} T$ cells as compared with $1^{\text {st }}$ injected mice (22.3 \pm 2.0 ) (Table 5).

PZQ administered mice showed non-significant change $(\mathrm{P}>0.05)$ in the mean \% of $\mathrm{CD}^{+} \mathrm{T}$ or $\mathrm{CD} 8^{+} \mathrm{T}$ or $\mathrm{B}$ cells as compared with the mean $\%$ of naïve MLN cells.

Schistosomula-PZQ administered mice showed unsignificant increments $(\mathrm{P}>0.05)$ in the mean \% of $\mathrm{CD} 4^{+} \mathrm{T}$ or $\mathrm{CD} 8^{+} \mathrm{T}$ or $\mathrm{B}$ cells as compared with the mean \% of MLN lymphoctes. They also showed non-significant increments $(\mathrm{P}>0.05)$ in the mean \% of $\mathrm{CD}^{+} \mathrm{T}$ cells as compared with the mean $\%$ of $\mathrm{CD}^{+} \mathrm{T}$ cells from schistosomula 1 st injected mice $(37.3 \pm 3.1$; fold $=1.11)$ or $2^{\text {nd }}$ injected mice (38.0 \pm 2.0 ; fold=1.09) or PZQ administered mice (39.5 \pm 2.9 ; fold $=1.05$ ) respectively. It was also observed that the mean $\%$ of
$\mathrm{CD}^{+} T$ cells from schistosomula-PZQ administered mice showed significant increase $(P<0.001)$ as compared with mean \% of $C D 8^{+} T$ cells from $1^{\text {st }}$ injected mice $(22.3 \pm 2.0)$ or PZQ administered mice (24.8 \pm 1.8 ; fold=1.25) respectively. However, it showed nonsignificant increase $(P>0.05)$ in $C D 8^{+} T$ cells mean \% as compared with $2^{\text {nd }}$ injected mice $(28.7 \pm 0.6$; fold $=1.08)$. They also showed non-significant increments $(P>0.05)$ when comparing the mean \% of B-MLN cells with the mean $\%$ of $B$ cells from $1^{\text {st }}$ injected mice $(38.0 \pm 3.9$; fold $=1.18)$ or $2^{\text {nd }}$ injected mice $(44.2 \pm 3.8$; fold $=1.01)$ or PZQ administered mice (38.3 \pm 5.2 ; fold=1.17) (Table 6).

\section{Discussion}

Our previous studies demonstrated that immunization with schistosomula associated with therapy were able to induce partial reduction in worm burden (68.5\%) against Schistosoma mansoni reinfection and modulate the immunocellular response [18]. We observed that injection with schistosomula stimulated the humoral immune response in naïve mice whereas, IgM and IgG levels were elevated in mice post injection with schistosomula alone or with PZQ or PZQ. De Melo et al. [19] detected significant levels of antischistosomula tegument (Smteg) IgG antibodies in the sera of mice injected with Smteg compared to control group. This is also is in accordance with the results of de Melo et al. [20] who transferred sera from mice immunized with Smteg or $\mathrm{Smp}-80$ to a naïve recipient and that was able to induce partial protection against challenge infection. Our data allowed us to speculate that, PZQ administration enhanced the humoral response in naïve mice. The IgM and IgG levels elevation observed in PZQ administered mice may reflect the sensitization of more lymphocytes by specific PZQ action, which is in accordance with the low toxicity and good tolerance of the drug in animals and healthy human volunteers [21].

Table 5. Mean percentage of thymocytes from schistosomula or/and PZQ administered mice

\begin{tabular}{lccc}
\multicolumn{1}{c}{ Experimental group } & $\begin{array}{c}C D 4^{+} T \\
\text { (Mean } \pm \mathrm{SD} \text { ) }\end{array}$ & $\begin{array}{c}C D 8^{+} T \\
\text { (Mean } \pm \mathrm{SD})\end{array}$ & $\mathrm{CD4^{+ } / C D 8 ^ { + }}$ \\
\hline Group 1 & $42.0 \pm 2.3$ & $35.7 \pm 1.5$ & 1.178 \\
Group 2 & $42.3 \pm 3.3$ & $35.1 \pm 2.7$ & 1.200 \\
Group 3 & & & \\
$-1^{\text {st }}$ injection & $42.0 \pm 2.0$ & $33.1 \pm 2.1$ & 1.269 \\
$-2^{\text {nd }}$ injection & $43.2 \pm 1.3$ & $35.0 \pm 1.4$ & 1.234 \\
Group 4 & $43.6 \pm 1.9$ & $33.3 \pm 1.3$ & 1.309 \\
\hline
\end{tabular}

Group1: PBS administered mice; used as negative control.

Group 2: PZQ administered mice.

Group 3: Schistosomula injected mice $\left(1^{\text {st }}\right.$ and $2^{\text {nd }}$ dose).

Group 4: Schistosomula-PZQ administered mice.

Table 6. Mean percentage of mesenteric lymph nodes lymphocytes from schistosemula or/and PZQ administered mice

\begin{tabular}{lcccc}
\hline $\begin{array}{c}\text { Experimental } \\
\text { group }\end{array}$ & $\begin{array}{c}C D 4^{+} T-M L N \\
\text { (Mean } \pm \text { SD) }\end{array}$ & $\begin{array}{c}C D 8^{+} T-M L N \\
\text { (Mean } \pm S D)\end{array}$ & $\begin{array}{c}C D 4^{+} / C D 8^{+} \\
T \text {-ratio }\end{array}$ & $\begin{array}{c}B-M L N \\
\text { (Mean } \pm S D)\end{array}$ \\
\hline Group 1 & $38.1 \pm 2.4$ & $25.3 \pm 4.3$ & 1.51 & $36.4 \pm 3.4$ \\
Group 2 & $39.5 \pm 2.9$ & $24.8 \pm 1.8$ & 1.59 & $38.3 \pm 5.2$ \\
Group 3 & & & & \\
- 1st injection & $37.3 \pm 3.1$ & $22.3 \pm 2.0$ & 1.67 & $38.0 \pm 3.9$ \\
- 2nd injecttion & $38.0 \pm 2.0$ & $28.7 \pm 0.6$ & 1.33 & $44.2 \pm 3.8$ \\
Group 4 & $41.6 \pm 4.1$ & $31.1 \pm 0.9$ & 1.34 & $44.7 \pm 2.5$ \\
\hline
\end{tabular}

Group1: PBS administered mice; used as negative control.

Group 2: PZQ administered mice.

Group 3: Schistosomula injected mice ( $1^{\text {st }}$ and $2^{\text {nd }}$ dose).

Group 4: Schistosomula-PZQ administered mice. 
Cellular immune responses are also important in parasite elimination. Recent studies showed that protective immunity associated Th2 profile was observed in out-bred mice immunized with glyceraldehyde3-phosphate dehydrogenase (SG3PDH) and peroxiredoxin (TPX) [22]. Blocking IL-10 with neutralizing antibodies enables protection against challenge infection in mice previously infected with $S$. mansoni and treated with praziquantel [23]. In S. japonicum infection, blocking IL-17 with neutralizing antibodies enhances antibody production and protection in infected mice [24].

Although $\mathrm{CD}^{+} T$ cells are classically related to immune responses against intracellular pathogens, its role in schistosome elimination has been recently described. Immunization of mice with the S. japonicum 22.6/26GST coupled to sepharose 4B bead induced a significant reduction in parasite burden that was associated with an increase in the number of activated $C D 8^{+} T$ cells. These activated $\mathrm{CD}^{+} \mathrm{T}$ cells were able to promote death of parasite carrying host the major histocompatibility 1 (MHCl) molecules in its surface [9]. S. japonicum calreticulin is one of the immunostimulatory molecules released from radiation-attenuated schistosomula cells, might play a crucial role in conferring a Th1polarized immune response induced by radiation-attenuated cercariae/schistosomula in mice [25]

\section{Conclusion}

In the current our study, the schistosomula may be considered as immunostimulatory adjuvant by enhancing the humoral immunostimulating response of IgM and IgG levels. Furthermore, schistosomula stimulated the cellular immune response of thymus and mesenteric lymph nodes organs whereas the ratio of thymocytes and $\mathrm{MLN}-\mathrm{CD}^{+} / \mathrm{CD} 8^{+} \mathrm{T}$-lymphocytes $>1$. Also, and MLN-B cells were evoked. Of particular interest to this study, the schistosomula-PZQ administration was able also to stimulate the humoral and cellular immune responses also, the ratio of MLN$\mathrm{CD}^{+} / \mathrm{CD}^{+}$T-lymphocytes $>1$ and the mean percentage of MLN Blymphocytes was stimulated.

\section{Acknowledgements}

The authors acknowledge the National Research Centre of Egypt for providing all required facilities and logistics for the work. The authors acknowledged the National Research Centre for the financial support.

\section{Conflict of interest}

The authors declared no potential conflicts of interest with respect to the research, authorship, and/or publication of this article.

\section{Ethical approval}

All procedures performed in the study involving animals were in accordance with the ethical standards of the institution or practice at which the study was conducted.

Anesthesia procedures complied with ethical guidelines of the National Institutes of Health in the USA and were approved by the Medial Ethical Committee of the National Research Centre in Egypt with a registration's number 10135 .

\section{References}

1. WHO - World Health Organization. Schistosomiasis - PCT database. Geneva: WHO, 2015, 2016.

2. McManus DP, Loukas A. Current status of vaccines for schistosomiasis. Clin Microbiol Rev 2008; 21: 225-242. https://dx.doi.org/10.1128/CMR.0004607.
3. Cioli D. Praziquantel: Is there real resistance and are there alternatives? Curr Opin Infect Dis 2000; 13: 659-663. http://www.ncbi.nlm.nih.gov/pubmed/11964838.

4. Crellen $\mathrm{T}$, Walker $\mathrm{M}$, Lamberton $\mathrm{PH}$, Kabatereine NB, Tukahebwa EM, Cotton JA, et al. Reduced efficacy of praziquantel against Schistosoma mansoni is associated with multiple rounds of mass drug administration. Clin Infect 2016; 63: 1151-1159. https://dx.doi.org/10.1093/cid/ciw506.

5. Jiang N, Cai P, Yin J, Hao L, Lu H, Wang X, et al. Characterization of antibody responses to the $\mathrm{Sj} 23$ antigen of Schistosoma japonicum after infection and immunization. Acta Trop 2010; 116: 9-14. https://dx.doi.org/10.1016/j.actatropica.2010.04.015.

6. Fonseca, CT, Sergio CO, Clarice CA. Eliminating schistosomes through vaccination: what are the best immune weapons? Front Immunol 2015; 6: 95. https://dx.doi.org/10.3389/fimmu.2015.00095.

7. Kumar P, Ramaswamy K. Vaccination with irradiated cercariae of Schistosoma mansoni preferentially induced the accumulation of interferon-gamma producing T cells in the skin and skin draining lymph nodes of mice. Parasitol Int 1999; 48:109-119. https://doi.org/10.1016/S1383-5769(99)00008-2.

8. Pedras-Vasconcelos JA, Pearce EJ. Type $1 \mathrm{CD} 8+\mathrm{T}$ cell responses during infection with the helminth Schistosoma mansoni. Immunology 1996; 157: 3046-3053. https://www.ncbi.nlm.nih.gov/pubmed/8816414.

9. Zhou $Y$, Zhang $H$, Sun $X J$, Zheng $D$, Liang $Y J$, Luo J, et al. Murine CD8(+)T cell cytotoxicity against schistosomula induced by inoculation of schistosomal 22.6/26 GST coupled sepharose 4B beads. Vaccine 2012; 30: 2440-2447. https://dx.doi.org/10.1016/jvaccine.2012.01.068.

10. Knudsen NP, Olsen A, Buonsanti C, Follmann F, Zhang Y, Coler RN, et al. Different human vaccine adjuvants promote distinct antigenindependent immunological signatures tailored to different pathogens. Sci Rep 2016; 6: 19570. https://dx.doi.org/10.1038/srep19570.

11. Mountford AP, Harrop R, Wilson A. Antigens derived from lung-stage larvae of Schistosoma mansoni are efficient stimulators of proliferation and gamma interferon secretion by lymphocytes from mice vaccinated with attenuated larvae. Infect Immunol 1995; 63: 1980-1986. https://www.ncbi.nlm.nih.gov/pubmed/7729911.

12. Gobert GN, Chai M, McManus DP. Biology of the schistosome lungstage schistosomulum. Parasitology 2007; 134: 453-460. https://dx.doi.org/10.1017/S0031182006001648.

13. de Melo TT, Araujo JM, Duraes FDV, Caliari MV, Oliveira SC, Coelho $\mathrm{PM}$, Fonseca CT Immunization with newly transformed Schistosoma mansoni schistosomula tegument elicits tegument damage, reduction in egg and parasite burden. Parasite Immunol 2010; 32:749-759. https://dx.doi.org/10.1111/j.1365-3024.2010.01244.x.

14. Araujo JM, de Melo TT, de Sena IC, Alves CC, Araujo N, Duraes F, Oliveira SC, Fonseca CT. Schistosoma mansoni schistosomula tegument (Smteg) immunization in absence of adjuvant induce IL-10 production by CD4+ cells and failed to protect mice against challenge infection. Acta Tropica 2012; 124: 140-146. https://dx.doi.org/10.1016/i.actatropica.2012.07.007.

15. James ER, Taylor MG. Transformation of cercariae to schistosomula: a quantitative comparison of transformation techniques and of infectivity by different injection routes of the organisms produced. Helminthology 1976; 50: 223-33. https://www.ncbi.nlm.nih.gov/pubmed/1010921.

16. Maghraby AS, Bahgat $M$. Immunostimulatory effect of coumarin derivatives before and after infection of mice with the parasite Schistosoma mansoni. Arzneim Forsch 2004; 54:445-450. https://dx.doi.org/10.1055/s-0031-1297010.

17. Maghraby AS. Effect of bilharcid on the immune system of healthy and Schistosoma mansoni infected mice. MSc thesis. Faculty of Science, Cairo University, Egypt, 1989.

18. Maghraby AS, El-Shaer SS, Afify EA, Zahran HG, Abd El-Aleem RA. Immunomodulatory effect of schistosomula on reinfection and treatment. RJPBCS 2016; 7: 847-885. 
19. de Melo TT, Araujo JM, de Sena IC, Alves CC, Araujo N, Fonseca CT. Evaluation of the protective immune response induced in mice by immunization with Schistosoma mansoni schistosomula tegument (Smteg) in association with CpG-ODN. Microbes Infect 2013; 15: 28-36. https://dx.doi.org/10.1016/j.micinf.2012.10.007.

20. de Melo TT, Sena IC, Araujo N, Fonseca CT. Antibodies are involved in the protective immunity induced in mice by Schistosoma mansoni schistosomula tegument (Smteg) immunization. Parasite Immunol 2014; 36:107-111. http://www.ncbi.nlm.nih.gov/pubmed/24558655.

21. Ali BH. A short review of some pharmacological, therapeutic and toxicological properties of praziquantel in man and animals. Pak J Pharm Sci 2006; 19: 170-175. https://www.ncbi.nlm.nih.gov/pubmed/16751131.

22. El Ridi R, Tallima H. Vaccine-induced protection against murine schistosomiasis mansoni with larval excretory-secretory antigens and papain or type-2 cytokines. J Parasitol 2013; 99:194-202. https://dx.doi.org/10.1645/GE-3186.1.

23. Wilson MS, Cheever AW, White SD, Thompson RW, Wynn TA. IL-10 blocks the development of resistance to re-infection with Schistosoma mansoni. PLoS Pathog 2011; 7: e1002171. https://dx.doi.org/10.1371/journal.ppat.1002171.

24. Wen X, He L, Chi Y, Zhou S, Hoellwarth J, Zhang C, et al. Dynamics of Th17 cells and their role in Schistosoma japonicum infection in C57BL/6 mice. PLoS Negl Trop Dis 2011; 5: e1399. https://dx.doi.org/10.1371/journal.ppat.1002171.

25. Ma L, Li D, Yuan C, Zhang X, Ta N, Zhao X, et al. SjCRT, a recombinant Schistosoma japonicum calreticulin, induces maturation of dendritic cells and a Th1-polarized immune response in mice. Parasites \& Vectors 2017; 10:570. https://dx.doi.org/10.1186/s13071-017-2516-7.

Authors:

Reham A. Abdel Aleem - MSc, Assistant Researcher, Department of Therapeutic Chemistry, Pharmaceutical and Drug Industries Research Division, National Research Centre, Dokki, Giza, Egypt. http://orcid.org/0000-0001-7184-4882.

Shreen S. El-Shaer - PhD, Professor Doctor, Department of Biochemistry, Faculty of Pharmacy (Girls), Al-Azhar University, Cairo, Egypt. http://orcid.org/0000-0001-9835-8913.

Essam A. Afify - PhD, Professor Doctor, Faculty of Medicine (Boys), AlAzhar University, Cairo, Egypt.

Razin M. Abder Fattah - MSc, Assistant Researcher, Department of Therapeutic Chemistry, Pharmaceutical Industries and Drug Research Division, The Group of Immune and Biomarkers for Infectionv (Centre of Excellent for Advanced Science), National Research Centre, Dokki, Giza, Egypt. http://orcid.org/0000-0003-1900-6632.

Kareem S. Awad - MSc, Assistant Researcher, Department of Therapeutic Chemistry, Pharmaceutical Industries and Drug Research Division, The Group of Immune and Biomarkers for Infectionv (Centre of Excellent for Advanced Science), National Research Centre, Dokki, Giza, Egypt. http://orcid.org/0000-0003-1007-9632.

Amany S. Maghraby - PhD, Professor Doctor, Department of Therapeutic Chemistry, Pharmaceutical Industries and Drug Research Division, The Group of Immune and Biomarkers for Infectionv (Centre of Excellent for Advanced Science), National Research Centre, Dokki, Giza, Egypt. http://orcid.org/0000-0002-9723-5011. 